\title{
CHEMICAL COMPONENTS OF LANTANA (LANTANA CAMARA L) AND LEMONGRASS (CYMBOPOGON CITRATUS "DC." STAPF.) PLANTS IN EGYPT
}

\author{
A.M. Batt and M.S. Ahmed \\ Plant Protection Research Institute, ARC, Dokki, Giza, Egypt
}

Received: May 7, 2016

Accepted : May 21, 2016

ABSTRACT: The aim of the present investigation is to study the chemical components of two plant species, lantana (Lantana camara) and lemongrass (Cymbopogon citratus). Plant materials were extracted successively by using four solvents of ascending polarity (Petroleum ether, chloroform, acetone and ethanol, respectively).

The fatty acids, unsaponifiable matter, volatile oils, photochemical screening and the active components were determined.

The results of this work showed that:

1-The presence of five saturated fatty acid and seven unsaturated fatty acids in Lantana camara, while lemongrass showed seven saturated fatty acids and five unsaturated fatty acids.

2- Lantana camara unsaponifible matter showed the presence of 16 compounds, while lemongrass showed 14 compounds.

3- GC/Ms Lantana camara volatile oil showed the presence of 31 compounds, while lemongrass volatile oil showed 13 compounds.

4- Lantana camara had higher percentage of total sterols (12.23\%) than that of lemongrass (6.91\%). Total falvonoids were higher in Lantana camara $(219.19 \mathrm{mg} / \mathrm{g}$ than that lemongrass (17.54mg/g).

Total carbohydrates, proteins and fat contents were higher in lemongrass than that Lantana camara.

Key words: Chemical components, Extract, Lantana camara, Cymbopogon citrates, Analysis.

\section{INTRODUCTION}

Several researchers are attempting to develop phytochemical based strategies for pest control. Compounds involved in plant pest interaction include repellents, attractants, hatching stimulatants or inhibitors and toxicants. These interactions have greater attention because of the growth of discipline of allelochemicals .

Different parts of some plants contain volatile odoriferous substances that affect the olfactory sence and are responsible for the fragrance. Volatile oils constitute the most principles odorous found in various plant parts. Volatile oils represent the essence of the active constituents of such plants.

Chitwood (2002) reported that certain plant parts extracts posses pesticidal properties. These plants have yielded a broad spectrum of active compounds toward different pests.

Many investigators have experiments on the effect of the lantana and lemongrass extracts on certain insect pests. So that, the chemical components of two plants, lemongrass (Cymbopogon citrates) and lantana (Lantana camara) was studied to determine the major constituents of these plants which are widely distributed in Egypt. 


\section{MATERIALS AND METHODS}

Samples of Lantana camara (Fam. Verbenaceae) and Cymbopogon citratus (Fam. Gramineae) plants, free from insecticidal contamination were obtained. The samples were dried at room temperature for two weeks and ground in an electric mill into fine powder, sieved and kept for extraction. Plant extracts were prepared according to the method adopted by Freedman et al., (1979). Hundred grams of these ground plant materials were extracted successively in a Soxhlet apparatus by using four solvents of ascending polarity as follows : Petroleum ether $\left(40-60{ }^{\circ} \mathrm{C}\right)$, chloroform, acetone and ethanol respectively. Each extract was evaporated under vacuum pressure using a rotary evaporator. The weight and the percentage of each crude extract was calculated. The crude extract was kept in refrigerator $\left(-4^{\circ} \mathrm{C}\right)$ till chemical studies. The volatile oils were obtained by hydrodistillation using Clevenger apparatus, as conducted by Anderson et al., (1980).

\section{Chemical investigatior:}

1- Saponification of petroleum ether extract of lantana and lemon grass oils:

Saponification was carried out according to Farag et al., (1986).

\section{a- Extraction of fatty acids}

The oqueous layer (Saponifiable portion) remained after the extraction of unsaponifiable compounds was acidified with $\mathrm{HCL}(10 \% \mathrm{v} / \mathrm{v})$ to liberate the fatty acids, then extracted several times with petroleum ether till complete extraction. The percentage was calculated as reported by Farag et al., (1986) to identify the constituents of fatty acids, the obtained residue was transformed to their corresponding methyl esters.

\section{b- Preparation of fatty acid methyl esters}

fatty acids methyl esters were prepared and purified according to the method of Kinsella (1966). Fatty acids were analyzed by GLC to identify their constituents.

\section{c- Identification and quantitative determination of fatty acids by gas liquid chromatography (GLC).}

The fatty acids methyl esters were analyzed by Variangas chromatography model 3700 equipped with flame ionization detector (FID), and a stainless steel column (12 feet $x^{1} / 8$ " I.D.), packed with $15 \%$ DEGS on 80-100 mesh chronosorb (W-AW). The percentage composition for each component of the fatty acids mixture was calculated by the compensated normalization method using PU 4815 computing integrator attached to the GC.

\section{2- Gas chromatography/ Mass spectrometry analysis :}

GC/MS analysis was carried out to identify and determine the unsaponifiable matters and volatile oils composition of the two plants under investigation.

\section{3- Preliminary phytochemical screening tests :}

The dried extracts were analyzed for detection of carbohydrates and/or glycosids, terpenoids, sterols, flavonoids, tannins, saponins, alkaloids and proteins.

\section{* Test for carbohydrates and/or glycosids :}

An intense violet color appeared between the junction of the two layers confirm the presence of carbohydrates or a compound containing carbohydrates moiety as reported by Lewis and Smith (1967). 
* Test for unsaturated sterols and/or triterpenes :

one gram sample was extracted according to Hanson (1972).

Two tests were carried out .

\section{a- Liebermann - Burchard test}

A reddish violet ring was observed at junction of the two layers indicating the presence of unsaturated sterols and/or triterpenes.

\section{b- Salkowski test :}

A yellow color changing to orange and then red was produced, indicating the presence of sterols and/or triterpens.

\section{* Flavonoids test :}

About $10 \mathrm{gr}$. of each extract sample was used according to Geissman (1961). The presence of flavonoids appeared as follows.

a- Yellow color with sodium hydroxide.

b- Red color with concentrated hydrochloric acid and magnesium.

\section{* Tannins test:}

Shellard (1957) indicated to the presence of tannins was determine by greenish color which changes to bluish black or precipitate.

\section{* Test for saponins :}

Harborne (1998) indicated the presence of saponins if a voluminous froth was developed and persisted for almost $4 \mathrm{hr}$.

\section{* Test for alkaloids and/or nitrogenous bases:}

Mayer's reagent, Wagner reagent or Dragendorff's reagent were used. If no precipitate was formed in each case, that indicate the absence of alkaloid and/or nitrogenous bases as mentioned by Farnworth et al., (1964).

\footnotetext{
* Protein content :

The percentage of protein was computed by multiplying the equivalent nitrogen
}

content by the factor 6.25 (Anonymous, 1962).

\section{4- Quantitative determination :}

1- Determine of total carbohydrate : Phenol sulphuric acid method for total carbohydrate according to (Dubois et al., 1956).

2- Determine of total protein according to Lowry et al., (1951) method.

3- Determination of flavonoids : flavonoids were determine according to Zhuang et al., (1992).

4- Determination of total tannins : the present of tannins in the sample was calculated by the following formula:

1 gr. of copper oxide Cuo $=1.305 \mathrm{gr}$. tannins (Balbaa, 1974).

\section{RESULTS AND DISCUSSION}

The percentages of volatile oils and the different gradual extracts of Lantana camara and Lemon grass leaves.

Data in Table 1. indicated that the percentage of the volatile oil (fresh basis) in lemon grass leaves $(1.25 \%)$ was higher than that of Lantana leaves $(0.2 \%)$. The total lemon grass solvent extracts (dry basis) was in the same ratio as that of Lantana (12.83 and $12.81 \%$, respectively).

\section{Fatty acids composition :}

The GLC chromatogram of Lantana camara oil indicates the presence of five saturated fatty acids and seven unsaturated fatty acids, Table (2). The saturated fatty acids represented $50.65 \%$, while the unsaturated represented $49.35 \%$. Also, Lantana camara characterized by the presence of long chain unsaturated fatty acids as erucic, docosadienoic and docosatrienoic acids, similar results were obtained by Khan et al., (2003). The lemongrass GLC chromatogram indicates the presence of seven saturated fatty acids 
and five unsaturated fatty acids, (Table 2). The saturated fatty acids represented $33.63 \%$ while the unsaturated fatty acids showed $66.37 \%$, platmitic was the major saturated acid (37.32 and $18.31 \%$ ), while lenolenic was the predominant unsaturated fatty acid $(21.21 \%$ and $31.25 \%)$ in both lantana and lemongrass, respectively.

Table (1): Percentage of volatile oils and different gradual extracts of lantana and lemongrass leaves.

\begin{tabular}{|c|c|c|c|c|c|}
\hline \multirow{2}{*}{\multicolumn{2}{|c|}{ Solvent extracts }} & \multicolumn{4}{|c|}{ Percentage of extracts } \\
\hline & & \multicolumn{2}{|c|}{ Lantana } & \multicolumn{2}{|c|}{ Lemongrass } \\
\hline \multicolumn{2}{|c|}{ Volatile oils (Fresh basis } & \multicolumn{2}{|c|}{0.20} & \multicolumn{2}{|c|}{1.25} \\
\hline \multirow{2}{*}{ Non. Polar } & Petroleum ether & 1.43 & \multirow{2}{*}{6.08} & 3.64 & \multirow{2}{*}{5.56} \\
\hline & Chloroform & 4.65 & & 0.95 & \\
\hline \multirow{2}{*}{ Polar } & Acetone & 5.30 & \multirow{2}{*}{6.73} & 6.87 & \multirow{2}{*}{8.24} \\
\hline & Ethanol & 1.43 & & 1.37 & \\
\hline \multicolumn{2}{|c|}{$\begin{array}{c}\text { Total } \\
\text { Dry (weight basis) }\end{array}$} & & 12.81 & & 12.83 \\
\hline
\end{tabular}

Table (2): GC of fatty acid methyl esters of Lantana camara and lemongrass leaves.

\begin{tabular}{|c|c|c|c|c|c|}
\hline \multirow{3}{*}{\multicolumn{2}{|c|}{ Fatty acids }} & \multicolumn{4}{|c|}{$\%$ of fatty acids } \\
\hline & & \multicolumn{2}{|c|}{ Lantana camara } & \multicolumn{2}{|c|}{ Lemongrass } \\
\hline & & Saturated & Unsaturated & Saturated & Unsaturated \\
\hline Caprylic & C 8:0 & & & 0.84 & \\
\hline Capric & C 10:0 & & & 0.51 & \\
\hline Lauric & C 12:0 & 0.29 & & 3.70 & \\
\hline Myristic & C 14:0 & 5.82 & & 4.14 & \\
\hline Palmitic & C 16:0 & 37.32 & & 18.31 & \\
\hline Palmitoleic & C $16: 1$ & & 0.93 & & 2.47 \\
\hline Stearic & C 18:0 & 4.77 & & 4.22 & \\
\hline Oleic & C $18: 1$ & & 5.05 & & 11.11 \\
\hline Lindeic & C $18: 2$ & & 9.96 & & 18.72 \\
\hline Linolenic & C $18: 3$ & & 21.21 & & 31.25 \\
\hline Eicosamoic (Arachidic) & C 20:0 & 2.45 & & 1.91 & \\
\hline Erucic acid & C 22:1 & & 5.79 & & 2.82 \\
\hline Docosadienoic & C 22:2 & & 2.86 & & \\
\hline Docosatrirnoic & C 22:3 & & 3.55 & & \\
\hline Total & & 50.65 & 49.35 & 33.63 & 66.37 \\
\hline
\end{tabular}




\section{GC/MS of unsaponificable matter content:}

Data on GC/MS of unsaponificable matter (residue) of Lantana camara and lemongrass leaves are shown in Tables $(3$ and 4).

\section{1- Lantana camara}

Unsaponificable matter chromatogram shows the presence of 16 compounds. Undecae was the major hydrocarbon $(35 \%)$, followed by decane $(12.84 \%)$, cymene $(7.26 \%)$, dodecane $(6.48 \%)$, decane-2methyl (5.21\%), decane-4-methyl (5.92\%), cyclohexane-butyl $(3.65 \%)$ and trans caryophyllene (3.3\%). Other compounds represent less than $3.00 \%$. Sterols including campestral (2.04\%), B-sitosteral (5.45\%) and stigmasterol (1.59\%) represent $9.08 \%$ of total unsaponifiable matter, (Table 3 ).

\section{2- Lemon grass :}

GC/MS of lemon grass unsaponificable matter (Table 4) indicate the presence of 14 compounds. Geranial was the major component (39.64\%) followed by phytol (12.24\%), Juniper camphor (8.17\%), Geraniol (7.57\%), 1-hexadecanol (6.25\%), carpophyllene oxide $(3.90 \%)$, carophyllene (3.89\%), a-cis-bergamotene (3.52\%), 2pentadecanone 6,10,14 trimethyl (3.17\%), Linalol (2.74\%), Farnesene (2.22\%) and 6 methyl-5-heptene-2 one (2.09\%). Sterols as B-sitrol $(2.13 \%)$ and stigmasterol (2-45\%) were found in ratio of (4.58).

Table (3): GC/MS of unsaponificable matter of Lantana camara leaves.

\begin{tabular}{|c|l|c|c|}
\hline Peak No. & Compound & RRT & $\%$ \\
\hline 1 & Decane & 0.73 & 12.84 \\
\hline 2 & Decane-4-methyl & 0.79 & 5.92 \\
\hline 3 & Cyclohexane-butyl & 0.82 & 3.65 \\
\hline 4 & Cymene & 0.88 & 7.26 \\
\hline 5 & Decane-2-methyl & 0.90 & 5.21 \\
\hline 6 & Decane-3-methyl & 0.91 & 2.25 \\
\hline 7 & Undecane & 1.00 & 35.00 \\
\hline 8 & Benzaldehyde-4 (methyl ethyl) & 1.10 & 1.68 \\
\hline 9 & Nopyl acetate & 1.13 & 2.99 \\
\hline 10 & Undecane-2-methyl & 1.16 & 2.39 \\
\hline 11 & Naphthalene & 1.22 & 1.85 \\
\hline 12 & Dodecane & 1.25 & 6.48 \\
\hline 13 & Trans caryophyllene & 1.78 & 3.30 \\
\hline 14 & Campesterol & 2.42 & 2.04 \\
\hline 15 & B-sitosterol & 2.10 & 5.45 \\
\hline 16 & Stigmasterol & 2.70 & 1.59 \\
\hline & & & \\
\hline
\end{tabular}


Table (4): GC/MS of unsaponificable matter of lemongrass leaves.

\begin{tabular}{|l|l|l|l|}
\hline Peak No. & \multicolumn{1}{|c|}{ Compound } & \multicolumn{1}{c|}{ RRT } & \multicolumn{1}{|c|}{$\%$} \\
\hline 1 & 6-methyl-5-hepten-2-one & 0.51 & 2.09 \\
\hline 2 & Linalool & 0.72 & 2.74 \\
\hline 3 & Geraniol & 0.95 & 7.57 \\
\hline 4 & Geranial & 1.00 & 39.64 \\
\hline 5 & Caryophyllene & 1.29 & 3.89 \\
\hline 6 & a-cis-Bergamotene & 1.31 & 3.52 \\
\hline 7 & Farnesene & 1.40 & 2.22 \\
\hline 8 & Caryophyllene oxide & 1.54 & 3.90 \\
\hline 9 & Juniper camphor & 1.66 & 8.17 \\
\hline 10 & 2-pentadecanone 6,10,14 trimethyl & 1.90 & 3.17 \\
\hline 11 & 1-hexadecanol & 1.96 & 6.25 \\
\hline 12 & Phytol & 2.24 & 12.24 \\
\hline 13 & B-sitosterol & 2.42 & 2.13 \\
\hline 14 & Stigmasterol & 2.62 & 2.45 \\
\hline
\end{tabular}

\section{GC/MS of volatile oils :}

Data concerning the percentages of different volatile oil constituents of Lantana camara and lemon grass are showen in Tables 5 and 6 .

\section{1- Lantana camara}

GC/MS Lantana camara volatile oil detected thirty one compounds. The main components were $B$. caryophellene (10.1\%), B-phellandrene (7.81\%), pentane 3-methyl (7.22\%), a-caryophellene (6.89\%), 1,8-cineole (eucalyptol) 6.59\%, nerolidol $(5.25 \%)$ and germacrene D $(4.42 \%)$. Lantana camara essectial oil was characterized by a high percentage of sesquiterpenes. The obtained results are in agreement with the results reported by Abdel Hady et al., (2005).

\section{2- Lemon grass :}

GC/MS lemon grass volatile oil showed the presence of thirteen components. Geranial (49.14\%), neral (37.76\%) and myrcene $(8.20 \%)$ were the prevalent constituents representing $95.1 \%$ of the total volatile oil. Pulegone represented $1.52 \%$, while the other constituents were found in low percentages (less than $0.5 \%$ ). These findings are line with those reported by Chisowa et al., (1998), Mohd et al., (2004) found that lemon grass oil contained high amounts of monoterpens $(94.9 \%)$ and geraninal $(52.3 \%)$.

\section{Phytochemical screeing :}

Table (7) shows preliminary phytochemical screening of different extracts of Lantana camara and lemon grass leaves. Saponins and alkaloids were not detected in the two plant extracts. Petroleum ether and chloroform extracts of two plants contained terpenes and sterols. Acetone extracts contained flavonoids and tannins only while ethanol extracts of the two plant leaves comprised flavonoids, tannins, carbohydrates and/or glycosides and proteins. Also, Lantana camara ethanol extract showed the presence of terpenoids. Similar results were obtained by Rajesh and 
Verma (2006), while Osman and Radwan (2004) reported that active components of the ethanolic extract of lemon grass could be nitro, amino or terpene. Also, Mohd et al., (2004) found that lemon grass contained high amounts of monoterpens.

Table (5): GC/MS of the volatile oil of Lantana camara leaves.

\begin{tabular}{|c|c|c|c|}
\hline Peak No. & Compound & RRT & $\%$ \\
\hline 1 & Hexane & 0.05 & 1.23 \\
\hline 2 & Pentane-3-methyl & 0.06 & 7.22 \\
\hline 3 & a-pinene & 0.23 & 2.76 \\
\hline 4 & Camphen e & 0.25 & 1.23 \\
\hline 5 & B-phellandrene & 0.28 & 7.81 \\
\hline 6 & B-myrcene & 0.29 & 1.3 \\
\hline 7 & B-pinene & 0.31 & 1.68 \\
\hline 8 & Eucalyptol & 0.37 & 6.59 \\
\hline 9 & $1,3,6$, octatriene & 0.39 & 1.82 \\
\hline 10 & 3-carene & 0.40 & 2.96 \\
\hline 11 & Terpineol-z-beta & 0.48 & 2.37 \\
\hline 12 & Camphor & 0.55 & 1.24 \\
\hline 13 & Borneol & 0.59 & 0.99 \\
\hline 14 & 3-cyclohexene-1-01 & 0.61 & 1.24 \\
\hline 15 & $\alpha$-Terpineol & 0.63 & 1.04 \\
\hline 16 & Y-Pyronene & 0.85 & 2.86 \\
\hline 17 & Cyclohexane & 0.94 & 1.45 \\
\hline 18 & $\beta$-caryophellene & 1.00 & 10.1 \\
\hline 19 & Germacrene D & 1.01 & 4.42 \\
\hline 20 & a- Caryophyllene & 1.05 & 6.89 \\
\hline 21 & $\mathrm{\gamma}$ - Elemene & 1.11 & 3.68 \\
\hline 22 & 2,6 dimethyl-3-hydroxy pridine & 1.18 & 0.95 \\
\hline 23 & 1,3-Cyclohexanedial & 1.2 & 3.32 \\
\hline 24 & Nerolidol & 1.23 & 5.25 \\
\hline 25 & DI hydro-Neoclovene & 1.23 & 2.01 \\
\hline 26 & 3-heptanone & 1.24 & 4.25 \\
\hline 27 & 6 methyl-2-(4-methyl-3-cyclohexene) & 1.28 & 2.00 \\
\hline 28 & Bicylo (5.2.0) nonane & 1.31 & 3.75 \\
\hline 29 & Naphthalene & 1.32 & 1.84 \\
\hline 30 & $1 \mathrm{H}$-Indole-3-carboxylic acid & 1.34 & 2.34 \\
\hline 31 & Spiro (4.5) dec-8-en-7-one & 1.37 & 3.4 \\
\hline
\end{tabular}


Table (6): GC/MS of the volatile oil of lemongrass leaves.

\begin{tabular}{|l|l|c|c|}
\hline Peak No. & \multicolumn{1}{|c|}{ Compound } & RRT & $\%$ \\
\hline 1 & Myrcene & 0.445 & 8.20 \\
\hline 2 & Cis-Ocimene & 0.517 & 0.30 \\
\hline 3 & Trans- $\beta$ - Ocimene & 0.536 & 0.25 \\
\hline 4 & Linalool & 0.634 & 0.89 \\
\hline 5 & Trans-Chrysanthonal & 0.723 & 0.43 \\
\hline 6 & Pulegone & 0.787 & 1.52 \\
\hline 7 & Neral & 0.931 & 37.76 \\
\hline 8 & Geranial & 1.00 & 49.14 \\
\hline 9 & Geranial Acetate & 1.150 & 0.49 \\
\hline 10 & (Z, E) $\alpha$-Bergamoine & 1.235 & 0.34 \\
\hline 11 & 2-Tridecanone & 1.336 & 0.27 \\
\hline 12 & Caryophyllene oxide & 1.479 & 0.24 \\
\hline 13 & a-Gurjumene & 1.537 & 0.20 \\
\hline
\end{tabular}

Table (7): Phytochemical screening of different extracts of lemongrass and Lantana camara leaves.

\begin{tabular}{|c|c|c|c|c|c|c|c|c|}
\hline & \multicolumn{4}{|c|}{ Lantana camara } & \multicolumn{4}{c|}{ lemongrass } \\
\hline & $\begin{array}{c}\text { Pet. } \\
\text { Ether } \\
\text { extract }\end{array}$ & $\begin{array}{c}\text { Chloroform } \\
\text { extract }\end{array}$ & $\begin{array}{c}\text { Acetone } \\
\text { extract }\end{array}$ & $\begin{array}{c}\text { Ethanol } \\
\text { extract }\end{array}$ & $\begin{array}{c}\text { Pet. } \\
\text { Ether } \\
\text { extract }\end{array}$ & $\begin{array}{c}\text { Chloroform } \\
\text { extract }\end{array}$ & $\begin{array}{c}\text { Acetone } \\
\text { extract }\end{array}$ & $\begin{array}{c}\text { Ethanol } \\
\text { extract }\end{array}$ \\
\hline $\begin{array}{c}\text { Carbohydrates } \\
\text { or glycosides }\end{array}$ & -- & -- & -- & + & -- & -- & -- & + \\
\hline Flavoniods & - & -- & + & ++ & -- & -- & + & ++ \\
\hline Saponins & - & -- & -- & -- & - & - & -- & -- \\
\hline Tannins & -- & -- & + & ++ & -- & -- & + & ++ \\
\hline Sterols & ++ & ++ & - & -- & ++ & ++ & -- & -- \\
\hline Alkaloids & -- & -- & -- & -- & -- & -- & -- & -- \\
\hline Terpenoids & +++ & ++ & -- & -- & ++ & ++ & -- & + \\
\hline Proteins & -- & -- & -- & + & -- & -- & -- & + \\
\hline
\end{tabular}

- : Not detected ; + : Low amount ; ++ : High amount ; +++ : Highly amount

The percentages of the major constituents of Lantana camara and lemongrass leaves

Data in Table (8) showed that Lantana camara had higher percentage of total sterols $(12.23 \%)$ than that of lemon grass $(6.91 \%)$. Total amount of flavonoids was higher in Lantana camara $(29.19 \mathrm{mg} / \mathrm{g})$ than that of lemon grass $(17.54 \mathrm{mg} / \mathrm{g})$, also tannins content showed the same trend as flavonoids concerning solvent extracts, total amount of tannins was a higher in Lantana camara $(72.88 \mathrm{mg} / \mathrm{g})$ than lemon grass (59.73 $\mathrm{mg} / \mathrm{g})$. On contrary, total carbohydrates, proteins and fat contents were higher in lemon grass than that of Lantana camara . 
Table (8). percentage (amount) of major constituents of Lantana camara and lemon grass.

\begin{tabular}{|c|c|c|c|c|c|}
\hline \multirow{2}{*}{ Compound } & \multirow{2}{*}{$\begin{array}{l}\text { Solvent } \\
\text { extract }\end{array}$} & \multicolumn{2}{|c|}{ Lantana camara } & \multicolumn{2}{|c|}{ Lemongrass } \\
\hline & & $\%$ (amonnt) & Total & $\%$ (amonnt) & Total \\
\hline \multirow{2}{*}{ Sterols } & Pet. Ether & $9.08 \%$ & \multirow{2}{*}{$12.23 \%$} & $4.58 \%$ & \multirow{2}{*}{$6.91 \%$} \\
\hline & Chloroform & $3.15 \%$ & & $2.33 \%$ & \\
\hline \multirow{2}{*}{ Flavonoids } & Acetone & 3.00 mg/g & \multirow{2}{*}{$29.19 \mathrm{mg} / \mathrm{g}$} & $17.43 \mathrm{mg} / \mathrm{g}$ & \multirow{2}{*}{$17.54 \mathrm{mg} / \mathrm{g}$} \\
\hline & Ethanol & $26.19 \mathrm{mg} / \mathrm{g}$ & & $0.11 \mathrm{mg} / \mathrm{g}$ & \\
\hline \multirow{2}{*}{ Tannins } & Acetone & $25.39 \mathrm{mg} / \mathrm{g}$ & \multirow{2}{*}{$72.88 \mathrm{mg} / \mathrm{g}$} & $48.73 \mathrm{mg} / \mathrm{g}$ & \multirow{2}{*}{$59.73 \mathrm{mg} / \mathrm{g}$} \\
\hline & Ethanol & $47.49 \mathrm{mg} / \mathrm{g}$ & & $11.00 \mathrm{mg} / \mathrm{g}$ & \\
\hline Carbohydrate & Ethanol & $22.36 \%$ & 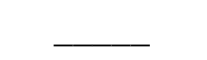 & $42.40 \%$ & \\
\hline Protein & Ethanol & $4.00 \%$ & 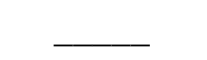 & $5.00 \%$ & \\
\hline Fat & Pet. Ether & $1.88 \%$ & 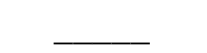 & $2.38 \%$ & 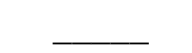 \\
\hline
\end{tabular}

Plant tannins act as growth inhibitor due to their action in binding with protein to form insoluble digestion inhibiting complexes (Martin et al., 1987). Also, tannins in the leaves play an important role as antifeedant agent.

The presence of tannins beside the low concentration of flavonoids play an important role for resistance of these plants againt the insects.

\section{REFERENCES}

Abdel-Hady, N.M., A.S. Abdel Halim and A.A. Ghadban (2005). Chemical composition and insecticidal activity of the volatile oils of leaves and flowers of Lantana camara L. cultivated in Egypt J. of the Egyptian Soc. of Parasitology. 35 (2): 687-698.

Anderson, B.A., R.T. Holman, L. Lundgren and G. Stenhagen (1980). Capillary gas chromatography of leaf volatiles. A possible aid to breeders for pest and disease resistance. J. Agric. Food chem.. 28: 985-989.
Anonymous (1962). Cereal laboratory methods seventh edition. Amer. Associ. Cereal Chem. ST-ponl. Minuesota, USA.

Balbaa, S.I. (1974). Chemistry of crude druge lanoratory minul. Al-Shaab printing house, Cairo, Egypt, pp 1-194.

Chisowa, E.H., D.R. Hall and D.I. Farman (1998). Volatile constituents of the essential oil of Cymbopogon citratus (xStapf. Grown in Zambia. Flavour and Fragrance J. 13; 1: 29-30.

Chitwood, D.J. (2002). Phytochemical based strategies for nematode control. Ann. Review of phytophath. Vol. 40: 22-249.

Dubois, M., F. Smith, K.A. Gilles, J.K. Hamilten and P.A. Rebers (1956). Colourimetric method for determination of sugars and related substances. Anal. Chem., 28 (3): 350-356.

Dwivedi, S.C. and G. Seema (2003). Toxicity evaluation of flower extract of lantana camara on the life cycle of Corcyra cephalonica. Indian J. of Entom. 65 (3): 330-334.

Farag, R.S., S.A.S. Hallapo, F.M. Hewedi and A.I.I. Basyony (1986). Chemical 
evaluation of rape seed oil. Fette. Sei Fen. Anstrichemittel, 88: 391-397.

Farnsworth, R., W. Loub, R. Blomster and M. Corman (1964). Pericylivine a new Catharanthus alkaloid. J. Pharm. Sci. 53: 1558-1567.

Freedman, B., L.J. Nouak and W.F. Kwolek (1979). Abioassay for plant - derived pest control agent using the Eiropean corn borer. J. Econ. Entomal. 72: 541545.

Geissman, T.A. (1961). Chemistry of flavonoids Pergmon press Co. London, 126.

Hanson, J.R. (1972). Chemistry of terpenes and terpenoids (Ed. A.A. Newman). Academic Press. New York. pp. 155-206.

Harborne, J.B. (1998). Phytochemical methods. A. guide to modern texhniques of plant analysis. New York, USA pp 54150.

Khan, M., S.K. Syamasunder, S.K. Neetujain and A.K. Yadav (2003). Chemical composition of fruit and stem essential oils of Lantana camara from northern India. Flavour and Fragrance Journal. 18 (5): 376-379.

Kinsella, J.E. (1966). Metabolic patterns of the fatty acids of Periplaneta Americana during the eniberyonic development. Can. J. Biochemistry. 44: 247-258.

Lewis, H. and C. Smith (1967). Sugar alcohols in fungi and green plants. Methods of detection and estimation.
New Phytol.; 66, 185-204. Refered to Harbrone, J.B. (1998). Phytochemical Methods, a guide to modern techniques of plant analysis, p. 54, New York, USA.

Lowry, O.J., N.J. Rosebrough, A.L. Parr and R.J. Randll (1951). Protein measurement with the folin reagent J. Biol. Chem. 193: 265-275.

Martin, J.S., M. Martin and E.A. Bernays (1987). Failure of tannic acid to inhibit digestion or reduce digestibility of plant protein ingut fluids of insect.

Mohd, A., S. Indu and S. Onkar (2004). Volatile constituents of Cymbopogon citratus Stapf. Leaves. Journal of Essential Oil Bearing Plants. 8 (1): 56-59.

Osman, S.M. and O.M. Radwan (2004). Isolation and Identification of active components in some plant extracts and their effect on Agrotis ipsilon (Hufn). Egyptian Journal of Biological Pest Centrol. 14 (1): 181-185.

Rajesh, K.V. and S.K. Verma (2006). Phytochemical and termiticidal study of Lantana camara var. Aculeata leaves. Firoterapia. 20: 1-3.

Shellard, E.J (1957). practical plant chemistry. London Ritman Medical publishing Co.Ltd.

Zhuang, X.P., Y.Y. Lu and G.S. Yang (1992). Extraction and determination of flavonoid in ginkgo Chinese Herbal Medicine, 23: 122-124. 
التركيب الكيماوى لنباتات اللانتانا Lantana camara وحشيشة الليمون في مصر Cymbopogon citratus

\section{عبد الغنى محمد بط ، محمد صابر أحمد} معهد بحوث وقاية النباتات ـ مركز البحوث الزراعية ـ الدقى . جيزة ـ مصر

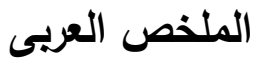

الهدف من هذا البحث هو دراسـة التركيب الكيماوى لكلا من نبات اللانتانا Lantana camara وحشيشـة الليمون Cymbopogen citratus وذلك باستعمال أربعة مذيبات متدرجة القطبية (بتروليم إيثر ـ الكلوروفورم . الاسيتون ـ الايثانول) على التوالى.هذا وقد تم دراسـة التركيب الكيماوى للاحماض الدهنية والجزء الغير متصبن والزيت الطيار حيث تم تقدير النسب المختلفة للمستخلصات النباتية والزيت والتعرف على المركبات الفعالة . وتثير نتائج هذا العمل إلى الآتى :1- وجود خمسة أحماض دهنية مشبعة وسبعة أحماص دهنية غير مشبعة فى نبات الانتانا أما حشيشة الليمون فقد

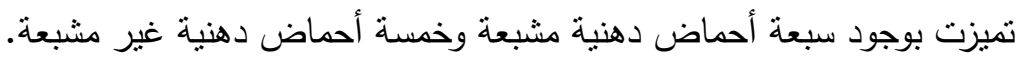

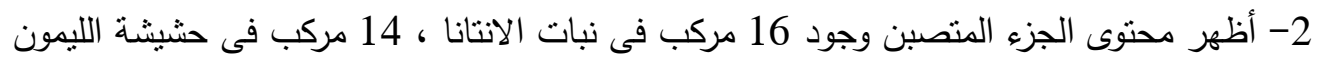

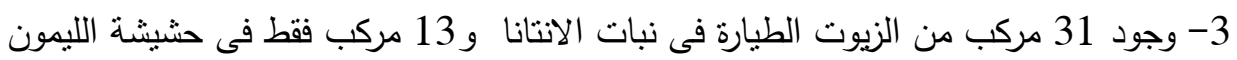

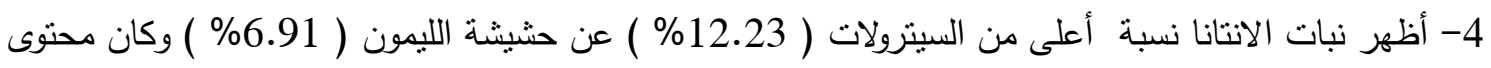
الفلافونويدز أعلى فى نبات الانتانا ( 29.19 مجم/جم) عن حشيشة الليمون (17.54 مجم/جمانم).

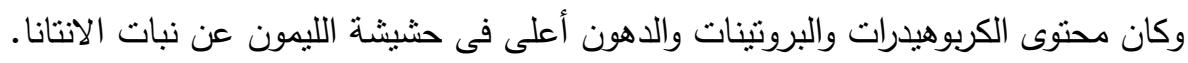


